\title{
Corrigendum: Response to Protocol Review Scenario: A word from OLAW and USDA
}

Patricia Brown, VMD, MS, DACLAM \& Chester Gipson, DVM

Lab Anim. (NY) 39, 234 (2010).

USDA incorrectly stated that Great Eastern should report to USDA the failure to follow the protocol as described in the scenario. The Animal Welfare Act and Regulations require the Institutional Official to report to USDA only if the IACUC suspends an activity involving animals (section $2.31(\mathrm{~d})(7)$ ) or if the institution fails to adhere to the plan and schedule to correct significant program or facility deficiencies (section $2.31(\mathrm{c})(3))$.

\section{Corrigendum: Morbidity and mortality rates associated with serial bleeding from the superficial temporal vein in mice}

Nadine Forbes, MS, Cory Brayton, DVM, Susan Grindle, MT (AMT), Starain Shepherd, BS, Betty Tyler, BS \& Michael Guarnieri, PhD Lab Anim. (NY) 39, 236-240 (2010).

The correct spelling of the fourth author's name is Starane Shepherd. 